\title{
ANÁLISE DO DISCURSO PUBLICITÁRIO: ESTRATÉGIAS DISCURSIVAS
}

\section{ANALYSIS OF THE ADVERTISING SPEECH: DISCURSIVE STRATEGIES}

Flávio Everton de Castro

Faculdades Promove

Belo Horizonte, MG, Brasil

E-mail: flavioedc@yahoo.com.br

\section{Luiz Cláudio Vieira de Oliveira}

Academia Cordisburguense de Letras João Guimarães Rosa, ACL - JGR, Brasil

Cordisburgo, MG, Brasil

E-mail: violi@superig.com.br

\section{Cristiana Fernandes De Muÿlder}

Professora Titular do Programa de Doutorado e Mestrado em Administração da Universidade FUMEC

Belo Horizonte, MG, Brasil

E-mail: cristiana.muylder@fumec.br

\section{RESUMO}

Este artigo analisa o discurso usado pela organização Hortifruti, como estratégia empresarial de marketing para aumentar a competitividade, atendendo as necessidades de consumo e satisfazendo o imaginário dos consumidores. A Hortifruti desenvolveu uma campanha publicitária, em quatro fases, com o emprego de elementos semiodiscursivos, que atendem os objetivos e estratégias de marketing. A pesquisa, qualitativa e descritiva, realizou um estudo de caso, realizando pesquisa de campo e entrevistas. Os recursos semiodiscursivos dos textos publicitários da campanha e as entrevistas foram analisados com a metodologia buscada à Análise do Discurso Francesa (ADF), que é uma teoria linguística e semiótica, de origem estruturalista. Os conceitos de marketing estratégico e de relacionamento forneceram o contexto para a análise discursiva efetuada. Os resultados alcançados permitem concluir que a eficácia das fases da campanha se deveu ao emprego de discursos linguísticos e imagéticos, comuns à cultura dos clientes da Hortifruti, que incluem elementos semióticos, além de metáforas, jogos de palavras, chistes e humor, e que funcionam como recursos para atração e retenção dos clientes.

Palavras-chave: Marketing. Anúncio publicitário. Discurso. Análise do Discurso. Semiolinguística.

\section{ABSTRACT}

This article analyzes the discourse used by Hortifruti organization as a business marketing strategy to increase competitiveness, meeting the needs and satisfying the imagination of consumers. The Hortifruti developed an advertising campaign in four stages, with the use of semiotic and discursive elements. The research, qualitative and descriptive, conducted a case study with the use of field research and interviews. The discursive resources of the campaign texts and interviews were analyzed with the methodology of the French Discourse Analysis (ADF), that is a linguistic and semiotic theory whose origin is structuralist. The concepts of strategic marketing and relationship furnished the context for the discursive analysis performed. The results allow us to conclude that the effectiveness of the phases of the campaign was due to the use of common culture of customer Hortifruti, including linguistic and semiotic elements imagistic discourses, and metaphors, puns, jokes and humor, and that act as tools for attracting and retaining customers.

Keywords: Marketing. Advertisement. Discourse. Discourse Analysis. Semiolinguistics.

Data de aprovação: 4 de junho de 2016.

Data de submissão: 7 de novembro de 2015. 


\section{INTRODUÇÃO}

No mundo contemporâneo, o processo de globalização e as transformações rápidas e radicais provocaram mudanças no modo de produção capitalista, com reflexos locais (ZENONE, 2011). Segundo Firat (2012, p. 82), o principal objetivo da globalização é a expansão dos mercados globais, para o crescimento da economia. E esse processo se faz também por meio do marketing. Para o autor, "Marketing is the institutionalization of practices through which market exchanges are organized and executed as imagined in modern culture" (FIRAT, 2012, p. 80). O marketing, com as estratégias e formas de gestão, é utilizado por empresas brasileiras, inclusive as de âmbito local ou regional, para se inserirem no processo e para obterem competitividade. Este artigo analisa os recursos semiodiscursivos utilizados pelas campanhas de marketing da organização Hortifruti, para suprir as necessidades e preferências dos consumidores, otimizar os lucros da organização e mantê-la no mercado, como parte de suas estratégias empresariais.

A Hortifruti comercializa produtos alimentícios. Localiza-se em Vitória - ES, e no Rio de Janeiro - RJ, em cujas lojas circulam mais de 1,6 milhões de clientes, comercializando 15 mil toneladas de frutas, legumes e verduras, mensalmente. Para ela, a empresa MP Publicidade desenvolveu, de 2003 a 2013, uma campanha veiculada na Revista O Globo (encarte do jornal O Globo), e em outdoors implantados em pontos de venda (PDV). Previsivelmente, os produtos anunciados eram frutas, verduras e legumes. Uma frase, no site da MP Publicidade, caracteriza o trabalho da empresa para a Hortifruti: "Um fã é mais valioso que um consumidor". ${ }^{1}$

Churchill Jr. e Peter (2000), Campomar e Ikeda (2006), Crocoo e Gioia (2006) e Kotler (2006) destacam a importância do marketing para as organizações. Kotler e Keller (2006, p. 4) afirmam que: "Marketing é um processo social por meio do qual pessoas e grupos de pessoas obtêm aquilo de que necessitam e o que desejam com a criação, oferta e livre negociação de produtos e serviços de valor com outros". Sequini (2013) destaca a influência do marketing sobre o processo de decisão de compra do consumidor. Frederico et al. (2014) sublinham a importância do marketing, na criação de valor para uma marca, e no desenvolvimento de elementos, como a atmosfera do ponto de venda, o ambiente externo e a fachada, a exposição dos produtos, o atendimento, a aparência da loja, que influenciam na atratividade e na retenção dos clientes, importantes para a Hortifruti.

No caso da Hortifruti, além desses elementos, para fazer essa oferta e atender preferências e necessidades dos consumidores, a campanha criou mensagens originais, reunindo imagens e linguagem. Essa campanha foi dirigida a um público específico, possuidor de uma cultura específica. Além do contato diário, no ponto de venda, onde foram observadas as reações aos vários elementos, esse público foi previamente pesquisado. A avaliação dos efeitos da campanha redundou no seu desdobramento em fases e em seu emprego para a tomada de decisão, aprendizagem organizacional, inovação e aperfeiçoamento dos processos organizacionais.

A campanha se desenvolveu em quatro fases. Cada uma delas utilizou estratégias discursivas, persuasivas, e foi analisada com procedimentos metodológicos buscados à Análise do Discurso Francesa (CHARAUDEAU, 2005, 2009, 2010; CHARAUDEAU; MAINGUENAU, 2006; PIETROFORTE, 2011), para a qual todo discurso é semiótico, linguístico e contextual. A Análise do Discurso Francesa (ADF) é uma teoria 

MUYLDER

e uma prática de análise textual e discursiva, cuja metodologia se liga às teorias estruturalistas, de origem linguística e antropológica, desenvolvidas inicialmente por Saussure (2006), desde a primeira edição de seu livro, em 1911, e, posteriormente, por Foucault et al. (1971), Foucault (1972), Barthes (1972, 1974), LéviStrauss (1975), Todorov (1979), Bakhtin (1981). Mais recentemente, teorias estruturalistas e discursivas têm sido utilizadas em abordagens como as de Bourdieu (1982) e Bauman (2001). Neste texto, pretende-se refletir sobre o discurso que representa e concretiza estratégias de marketing, e não sobre o próprio marketing. A metodologia empregada, com base na teoria e nas técnicas da ADF, irá analisar cada uma das fases. Não houve a intenção de empregar o paradigma positivista, tal como o caracteriza Castro Júnior (2015).

A primeira fase da campanha consiste em "depoimentos" dos produtos, caracterizados pelo slogan "Hortifruti: Pra quem quer o melhor". São falas de personagens, humanizados, que interpelam diretamente o consumidor/interlocutor. O abacaxi, por exemplo, afirma: "Aí, princesa, meu castelo é logo ali na Hortifruti”. A segunda fase decorreu do sucesso da anterior: os produtos viraram "celebridades", indo parar na capa de uma revista de famosos, a fictícia Cascas, paródia de uma conhecida revista semanal, voltada para a vida, eventos e curiosidades de personalidades do contexto nacional e internacional. O coco, como numa entrevista, declara: "Quando se está no topo, todos querem te derrubar".

O terceiro momento levou as "celebridades" para Hollywood. Nessa fase, os textos exploraram títulos de filmes. O coentro, por exemplo, estrela o filme "E o coentro levou". Nessa fase, o slogan é "Hortifruti: Aqui a natureza é a estrela". O quarto momento foram os ritmos musicais, em que os produtos aparecem como cantores, apresentando canções nacionais e internacionais, como o morango, que canta: "Descobri que morango é demais".

A sucessão das várias campanhas levou a uma sofisticação dos textos, que se tornaram mais densos, e cuja complexidade discursiva exigia uma abrangência cultural maior. Buscou-se investigar os elementos semiodiscursivos empregados na campanha da Hortifruti, propondo-se a seguinte questão de pesquisa: de que maneira o uso de recursos semiodiscursivos configura uma estratégia de atratividade e retenção de clientes? Para respondê-la, colocam-se os seguintes objetivos: analisar a estrutura semiodiscursiva dos textos publicitários da campanha, evidenciando os recursos linguísticos e semióticos utilizados; e caracterizar a estratégia de marketing como uma estratégia semiodiscursiva. 


\section{REFERENCIAL TEÓRICO}

O discurso dos textos publicitários da Hortifruti configura uma opção por uma estratégia de marketing: aquela que pretende convencer, seduzir e fidelizar clientes, criando um valor para a marca Hortifruti. Ao mesmo tempo, por um uso específico do discurso, cria uma cumplicidade com o leitor/cliente, utilizando o humor e informações culturais comuns ao conjunto de clientes. Antes de proceder à análise dos elementos discursivos da campanha da Hortifruti, torna-se necessário inserir esses elementos no contexto de marketing, a partir de que foram pensados. Para Nóbrega (2011), o bom humor constituiu-se como um recurso fundamental para criar empatia com o cliente.

Segundo Cobra (1992), marketing pode ser considerado um processo de planejamento e execução, desde a concepção, promoção e distribuição de ideais, mercadorias e serviços, para criar trocas que satisfaçam os objetivos individuais e organizacionais. Las Casas (1997) indica que o marketing inclui relações de troca, contemplando a satisfação e as necessidades de consumidores, ao mesmo tempo em que alcança os objetivos de uma organização.

O marketing busca descodificar como os clientes pensam, compreendem e lidam com a realidade, oferecendo as informações necessárias para os executivos tomarem decisões, com base no que sabem do ponto de vista dos clientes. O diálogo e a construção de relacionamentos estáveis e duradouros com esses clientes surgem como resposta ao desafio imposto pelas mudanças no ambiente competitivo e no comportamento dos clientes, e pela expectativa de como eles desejam ser atendidos (KOTLER, 2005). Nesse sentido, todo marketing é estratégico, uma vez que se faz sempre com uma visão de longo prazo. Neste texto, utilizam-se os conceitos de marketing estratégico e de marketing de relacionamento, que descrevem com mais pertinência o trabalho de marketing executado pela Hortifruti.

O marketing estratégico, segundo Zenone (2011, p. 5), "é relativo às funções que precedem a produção e a venda do produto. Inclui o estudo de mercado, a escolha do mercado-alvo, a concepção do produto, a fixação do preço, a escolha dos canais de distribuição e a elaboração de uma estratégia de comunicação e produção". O marketing estratégico assegura que as atividades de marketing da organização se adaptem às mudanças externas e possuam os recursos necessários para, efetivamente, fazer isso. As decisões relativas ao marketing estratégico orientarão os gestores organizacionais no seu planejamento estratégico, que significa um comportamento prospectivo de levantar os meios para atingir os fins, os objetivos de uma empresa, considerando determinado ambiente (CAMPOMAR; IKEDA, 2006). Os consumidores interagem com o sistema de marketing por meio dos comportamentos que manifestam. Segundo Mello (2006), o marketing é construído em cada contexto organizacional. Tudo irá depender do valor percebido pelo cliente, o que passa pelo produto (aparência, validade, qualidade), pelos serviços oferecidos (atendimento, amabilidade, empatia) e pela experiência emocional (ambientação da loja, publicidade, promoções). Para Oliver (1999, p. 34):

lealdade é um profundo compromisso de recomprar um produto/serviço consistentemente no futuro, causando, assim, compras repetidas da mesma marca ou do mesmo conjunto de marcas, independentemente de influências situacionais ou de esforços de marketing que teriam potencial para causar um comportamento de mudança. 
Holanda (2008, p. 23) adverte que a lealdade só é importante se resultar em lucratividade: "Se a lealdade do cliente é gerida com prudência e em associação com a lucratividade, pode ser a arma mais potente contra a concorrência ao arsenal de marketing da empresa".

As estratégias de fidelização estão interligadas às estratégias de marketing de relacionamento, o qual surgiu como uma tentativa de as organizações estreitarem relações com seus consumidores, orientadas para a satisfação das necessidades deles. O marketing de relacionamento consiste num esforço integrado das empresas para identificar, construir, manter e aprimorar relacionamentos individuais com clientes, em um processo de troca de benefícios de longo prazo (PARVATIYAR; SHETH, 2000; BERRY, 2002; GONÇALVES; MACHADO; MARQUES, 2012). Faria et al. (2014) afirmam que a implementação do marketing de relacionamento deveu-se à necessidade de atender o consumidor e de criar vantagens competitivas.

Entendido, portanto, de forma abrangente, o marketing de relacionamento tende a confundir-se com o próprio conceito do marketing tradicional, tornando-se uma espécie de síntese para os dias atuais (PARVATIYAR; SHETH, 2000; PALMER, 2002). Esses autores destacam o marketing de relacionamento como um instrumento capaz de aprimorar processos organizacionais, por meio de um conjunto de estratégias que visam a identificar e a satisfazer as necessidades do consumidor.

Uma das formas de reter/fidelizar clientes é pela divulgação das ideias e produtos da organização, concentrados no trabalho publicitário. O termo publicidade, segundo Sant'Anna (2002), é derivado de público - do latim publicus - que significa a qualidade do que é público, ou seja, tornar público um fato, uma ideia, objetivando induzir ou convencer alguém a tomar uma atitude favorável a algo, enquanto o termo propaganda identifica-se com o meio utilizado para a divulgação de ideias.

Considerando que o objetivo geral de um anúncio é o de persuadir as pessoas a usar um determinado produto, serviço ou ideia, Sandmann (2003), Machin e Van Leeuwen (2007) afirmam que a linguagem é fundamental na criação de um anúncio publicitário, pois os elementos linguísticos, quando utilizados de forma criativa, podem despertar a atenção do leitor/consumidor. É por meio do discurso, em que as palavras e as imagens possuem um papel fundamental na informação, manipulação ou divulgação de produto ou ideia, que a publicidade participa da sociedade de consumo. Do ponto de vista de Sant'Anna (2002), a publicidade torna conhecido um produto, um serviço ou uma firma e desperta nos consumidores o desejo pelo que está sendo anunciado. Cafferky (1999) refere que um desempenho além das expectativas satisfará o consumidor e o fará retornar, além de divulgar aos outros sobre suas boas experiências.

Segundo Kotler (2000), as mensagens podem ser apresentadas com inúmeros estilos: instantes da vida real, estilo de vida, fantasia, atmosfera ou imagem, musical, símbolo de personalidade, especialidade técnica, evidência e testemunhos. Para Kotler (2000, p. 602), "É necessário encontrar palavras que fiquem na memória e atraiam a atenção". Esse processo exige que as estratégias de marketing realizem a gestão da informação (dados obtidos acerca das preferências do consumidor) e a transformem em conhecimento, que são as mensagens publicitárias, cujo conteúdo serão os valores e estilos indicados por Kotler, tendo em vista que os contornos culturais influenciam o comportamento humano e, portanto, os comportamentos associados às compras e ao consumo (TORRES; ALLEN, 2009; SEQUINI, 2013).

As mensagens publicitárias são textos, verbais e, ou, não verbais, decorrentes de um discurso produzido em determinado contexto, cujas significações serão pesquisadas e analisadas pela Análise do Discurso $(A D)$. Além do elemento puramente linguístico do discurso, intratextual, há elementos intertextuais 
e contextuais, ou pragmáticos, que compõem a produção discursiva de um texto, qualquer que seja ele. $\mathrm{O}$ ato de linguagem, responsável pela produção do discurso, faz com que a interação entre emissor e receptor seja dinâmica e progressiva.

Sobre o ato de linguagem, Charaudeau (2010) destaca duas posições teóricas diferentes: a que o pensa realizado entre locutor e receptor ideais, em uma circunstância de comunicação neutra e com uma intencionalidade única do emissor, considerando a linguagem um ato transparente, ou seja, que esgota sua significação em si mesmo. E a que pensa "[...] o ato de linguagem como produzido por um emissor determinado, em um dado contexto sócio-histórico. Assim, a linguagem é um objeto não transparente [...] e o processo de comunicação não é o resultado de uma única intencionalidade" (CHARAUDEAU, 2010, p. 17, grifo do autor). Essa é a postura teórica e analítica que se adota neste artigo: a campanha da Hortifruti se situa num contexto competitivo, em que é necessário desenvolver estratégias de marketing mais eficazes que as da concorrência, para atrair e fidelizar clientes. Parte dessas estratégias se concretiza em textos publicitários que pretendem seduzir e persuadir os leitores, possíveis clientes. É necessário, portanto, examinar as relações que se estabelecem entre emissor e receptor.

Dessas premissas acerca da contextualização e opacidade do discurso, Charaudeau deriva as seguintes conclusões: a) o ato de linguagem é um objeto duplo, "[...] constituído de um Explícito (o que é manifestado) e de um Implícito (lugar de sentidos múltiplos que dependem das circunstâncias de comunicação)". b) Receptor e emissor são seres concretos, de carne e osso, que podem atribuir sentidos diferentes a um mesmo ato de linguagem. c) Emissor e receptor têm uma competência múltipla para compreender o sentido de atos de fala em contextos e em relações históricas diferentes, adaptando-se a essas circunstâncias. Charaudeau (2005, grifos acrescentados) caracteriza a Análise do Discurso como semiolinguística, o que retomará posteriormente no livro Linguagem e discurso (2010). É esse o conceito que se adota neste texto. Portanto, ao se falar em análise do discurso, está-se falando, também, de semiolinguística:

Eis porque a posição que tomamos na análise do discurso pode ser chamada de semiolinguística. Semio-, de "semiosis", evocando o fato de que a construção do sentido e sua configuração se fazem através de uma relação forma-sentido (em diferentes sistemas semiológicos), sob a responsabilidade de um sujeito intencional, com um projeto de influência social, num determinado quadro de ação; linguística, para destacar a matéria principal da forma em questão - a das línguas naturais. Estas, por sua dupla articulação, pela particularidade combinatória de suas unidades (sintagmático-paradigmática em vários níveis: palavra, frase, texto), impõem um procedimento de semiotização do mundo diferente das outras linguagens.

A partir de Patrick Charaudeau, percebe-se como se dá a junção entre o texto e o extratexto, entre o linguístico e o contextual. No plano extratextual, há o Sujeito Comunicante (EUc) e o Sujeito Interpretante (TUi). De um lado, há o comerciante/publicitário (EUc), que pretende vender um produto; de outro, há o consumidor (TUi), que pode vir a comprar esse produto. A mediação entre esses dois sujeitos é feita por um texto (um anúncio), concretizando um discurso. É dentro desse texto que se localizam os duplos do Sujeito Comunicante e do Sujeito Interpretante, respectivamente, o Sujeito Enunciador (EUe) e Sujeito Destinatário (TUd). O EUe constitui as estratégias do texto: é quem fala e como se fala: são as escolhas efetuadas para a produção do texto; o Sujeito destinatário é a imagem do consumidor, a quem se dirige a mensagem, receptor 
já previsto no texto. Essa imagem pode coincidir (ou não) com o destinatário real, o Sujeito Interpretante. Se há coincidência, a comunicação é um sucesso; se não há, a comunicação não se efetiva, nem o Sujeito Interpretante, extratexto, se deixa convencer ou seduzir. Essa coincidência é a condição para que haja o marketing de relacionamento.

Segundo Barbosa e Trindade (2003, p. 10), o texto produzido pelo discurso, especialmente o publicitário, pode ter uma natureza semiótica:

[...] sobre o processo de enunciação publicitário, esclarecemos que o enunciado, ou seja, aquilo que é dito (no âmbito linguístico), passa (na publicidade) a ser um espetáculo semiótico, ou seja, é um enunciado em linguagens sincréticas e híbridas, não é apenas aquilo que é dito, mas também inclui aquilo o que é dado a ver/escutar e a sentir [...] um espetáculo intersemiótico, que precisa ser analisado através de metodologia interdisciplinar.

Essa mistura entre elementos linguísticos e semióticos, empregada nos textos publicitários, constitui uma retórica - a arte de persuadir -, caracterizada como os recursos com os quais um texto é organizado para atingir o objetivo comunicativo que o autor (Sujeito Comunicante) deseja conquistar. As relações estratégicas e retóricas, em um texto, encaminham o seu conteúdo e condicionam a sua interpretação pelo Sujeito Interpretante, fazendo o texto atingir seus objetivos e transformando um leitor num consumidor de fato. A fusão entre retórica e publicidade é explicitada por Durand (1970), que atribui essa união ao fascínio exercido pelas imagens e figuras dentro da publicidade.

Por outro lado, a aplicação do discurso semiótico à comunicação mercadológica oferece subsídios para observação e sistematização dos signos, podendo contribuir para uma análise dos referentes propostos pelo material de divulgação e para os potenciais retornos de entendimento por parte do público receptor (FELDMANN; SANT'ANNA, 2007). De uma maneira geral, a semiótica estuda os diferentes tipos de linguagens, cujos signos podem ser icônicos, sonoros, gestuais, normalmente em complementação aos signos linguísticos usados no discurso. Segundo Santaella (1999), a Semiótica é uma ciência que investiga as linguagens existentes, examinando os fenômenos em seu significado e sentido. A mesma autora compreende que a semiótica se caracteriza como a teoria de todos os tipos de signos, códigos, sinais e linguagens. "Ela nos permite compreender palavras, imagens e sons em todas as suas dimensões e tipos de manifestações" (SANTAELLA, 2007, p. 59).

Além da ideologia, ligada à retórica e à persuasão, aspectos semânticos, morfológicos, sintáticos, fonológicos e contextuais são característicos dos textos publicitários. A linguagem publicitária utiliza argumentos racionais (convencimento) e emocionais (persuasão) para provocar o desejo de consumo. As figuras discursivas e recursos argumentativos estão presentes na elaboração da mensagem publicitária. A construção do texto para publicidade e propaganda utiliza os signos verbais e não verbais, as imagens, cuja unificação acontece quando os domínios material e imaterial se relacionam no signo (PEREZ, 2007).

Tanto a gestão do marketing quanto a gestão do conhecimento foram transformados em uma campanha que evoluiu em várias fases, e cujos textos publicitários utilizaram uma estrutura discursiva passível de ser descrita e analisada pela análise do discurso, como se verá a seguir. 


\section{METODOLOGIA}

Com base em Vergara (2008), esta pesquisa se caracteriza como qualitativa. Quanto aos fins, é descritiva, constituindo-se como um estudo de caso (YIN, 2005). A opção pela pesquisa qualitativa está de acordo com a escolha da Análise do Discurso como método de análise. A AD pensa o ato de linguagem como socialmente produzido por pessoas situadas num contexto sócio-histórico específico, que inserem no discurso as suas crenças, valores e significados, construindo um objeto não transparente, fruto de múltiplas intencionalidades. Quanto aos meios, é uma pesquisa de campo.

A escolha da campanha da Hortifruti se deu pela percepção de seu impacto e de sua repercussão na internet e pela sua diferença de outras campanhas de empresas semelhantes (HORTIFRUTI, 2009; LOYOLA, 2011; NUNES; FERREIRA; MOURA, 2012; JAPPE, 2014). Inicialmente, fez-se uma entrevista em profundidade com a publicitária da empresa MP Publicidade, responsável pelo desenvolvimento da campanha. Em lojas da Hortifruti, localizadas em Vitória, no Espírito Santo, e escolhidas aleatoriamente, fezse o contato informal com vendedores e observou-se o relacionamento destes com os clientes. Por recomendação da empresa, as entrevistas com os clientes foram bastante informais e não puderam ser gravadas, mas apenas anotadas. Foram colhidos 75 depoimentos, de 48 mulheres (64\%); e de 27 homens (36\%), apesar de $2(2,6 \%)$ homens não terem respondido. A entrevista buscou verificar a empatia entre clientes e empresa, a partir da recepção dos textos publicitários da campanha.

Para a análise dos textos da campanha, foram utilizados métodos semiolinguísticos da Análise do Discurso Francesa. As teorias mobilizadas dizem respeito à Linguística, à Análise do Discurso, aí incluindo a Semiolinguística, além de elementos da Nova Retórica, cujas teorias foram aproveitadas por Charaudeau $(2005,2009,2010)$, na estruturação de sua própria teoria, para compreender a variedade de recursos empregados pelos textos da campanha.

A análise do discurso tem, como propósito, revelar as estratégias que os textos mobilizam e construir interpretações para o significado desses textos, ou seja, os possíveis interpretativos, que Charaudeau (2009) define como: "as representações linguageiras das experiências dos indivíduos que pertencem a [...] grupos, enquanto sujeitos individuais e coletivos". A análise do discurso não pretende evidenciar uma verdade, única e anterior, mas indicar que a significação de um texto se faz como um processo, como um fluxo. A esse respeito, Charaudeau é bastante claro:

Analisar um texto não é pretender dar conta apenas do ponto de vista do sujeito comunicante, nem ser obrigado a só poder dar conta do ponto de vista do sujeito interpretante. Deve-se, sim, dar conta dos possiveis interpretativos que surgem (ou se cristalizam) no ponto de encontro dos dois processos de produção e de interpretação. O sujeito analisante está em uma posição de coletor de pontos de vista interpretativos e, por meio da comparação, deve extrair constantes e variáveis do processo analisado (CHARAUDEAU, 2010, p. 63, grifos acrescentados).

Além disso, a análise do discurso atenta aos aspectos externos à língua, inerentes a uma abordagem discursiva: os elementos históricos, socioculturais e ideológicos. Para tanto, na análise do discurso, o uso da língua está sempre aliado ao aspecto social e histórico. Segundo Orlandi (2007), a análise do discurso trabalha com a língua no mundo. Por isso, considera os processos e as condições de produção da linguagem, a partir do relacionamento entre a língua, seus falantes e as circunstâncias em que o discurso é realizado. 

MUYLDER

Para Orlandi (2001, p. 16), a Análise do Discurso deve problematizar as formas de ler e de produzir discursos, uma vez que a linguagem não é uma, nem transparente ou neutra: a linguagem é política, exigindo nossa interpretação. $A A D$ nos permite uma postura menos ingênua e mais reflexiva sobre a linguagem.

Dessa forma, a análise dos textos publicitários abaixo nos obriga a interpretar, a refletir sobre os processos de construção de sentido que, a partir do conhecimento sobre os leitores/clientes, a campanha da Hortifruti, em suas várias fases, realizou.

Figura 1 - Publicidades da primeira fase da campanha
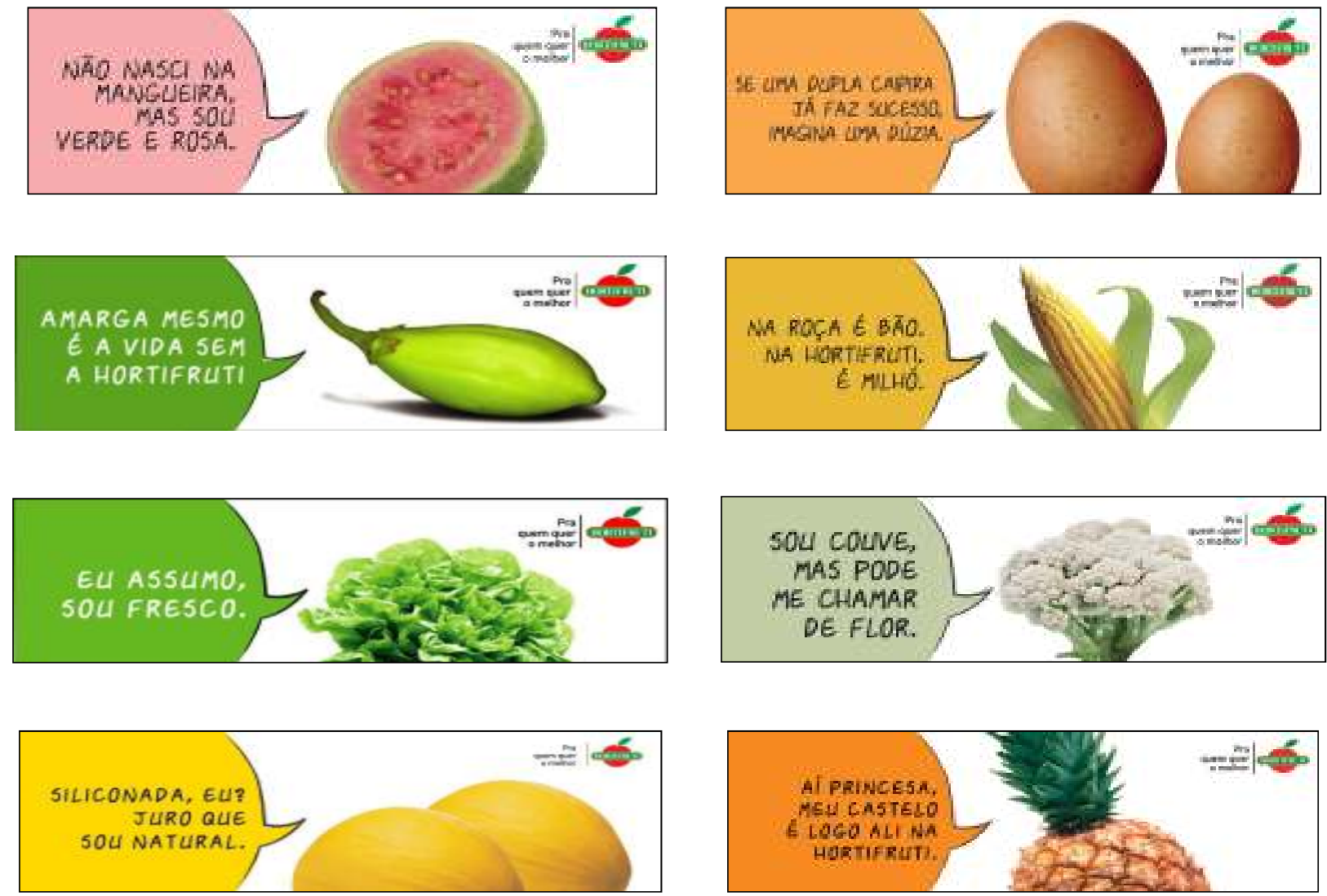

Fonte: www.hortifruti.com.br

Os textos que compõem o corpus deste trabalho utilizaram estratégias que incluem uma linguagem com jogos de palavras e uma multiplicidade de recursos, como os intertextos, as metáforas, trocadilhos, as metonímias, as paródias, a alusão, a ambiguidade, a prosopopeia, que é a atribuição de qualidades e sentimentos humanos a seres irracionais e inanimados, além do ritmo, e da rima. Todos esses recursos foram aliados às imagens que ilustram o texto e a outros elementos icônicos existentes nos anúncios.

Um dos recursos utilizados, a paródia, constitui uma forma contemporânea de prática da intertextualidade. Machado (1999) esclarece que "A paródia não teria assim uma função "destrutiva" [...], mas uma função "renovadora", ou seja, ela vem substituir formas "desgastadas" ou quase esquecidas por novas formas criadas, no entanto, a partir das antigas". Para Charaudeau e Mainguenau (2006), a paródia é uma forma de intertextualidade. 
Deve-se destacar o papel que desempenha o cliente, que é leitor/consumidor. Koch (2011, p. 97) acrescenta que textos requerem a participação ativa do leitor, para que a mensagem seja efetivada: "Por ocasião da produção, o locutor já prevê essas inferências, na medida em que deixa implícitas certas partes do texto, pressupondo que tais colunas venham a ser preenchidas sem dificuldades pelo interlocutor com base em seus conhecimentos prévios".

Neste trabalho, analisaram-se as seguintes fases da campanha publicitária: Depoimentos dos produtos ( $1^{\circ}$ fase), "Cascas, as estrelas da natureza em revista", ( $2^{\mathrm{a}}$ fase), "A Hortifruti apresenta: Em cartaz, na Hortifruti mais perto de você" ( $3^{\mathrm{a}}$ fase), "Ritmos musicais" ( $4^{\circ}$ fase). A duplicidade de sentidos, que se encontra nos anúncios, não apenas atrai a atenção do destinatário, induzindo-o a parar, ler e interpretar a mensagem que the é dirigida, como também mistura o universo dele com o mundo da Hortifruti, tal como nos diz Sandmann (2003, p. 74): "Qual o sentido dessa duplicidade de sentido? [...] É fazer um jogo com as palavras, é entreter o destinatário, desafiá-lo a entender a mensagem, prender sua atenção, enfim, e, em última análise, fazê-lo consumir o produto ou servir-se de um serviço".

O humor é um dos recursos intencionalmente buscados para seduzir o público-alvo, criando uma relação prazerosa entre leitor e mensagem, e ultrapassando as barreiras do racional (CARVALHO, 2004). Apesar de localizar-se num outro contexto, o artigo de Isabella, Barros e Mazzon (2015) destaca a importância da emoção para o processo de compra. O humor tem a finalidade de tocar o leitor e fazê-lo criar ligações emocionais positivas com os produtos, que evocam situações vivenciadas por ele, e influenciando suas decisões de compra:

Chamamos a atenção para isso: não há comicidade fora do que é propriamente humano. Uma paisagem poderá ser bela, graciosa, sublime, insignificante ou feia, porém jamais risível. Riremos de um animal, mas porque teremos surpreendido nele uma atitude de homem ou certa expressão humana. Riremos de um chapéu, mas no caso o cômico não será um pedaço de feltro ou palha, senão a forma que alguém Ihe deu, o molde da fantasia humana que ele assumiu (BERGSON, 1983, p. 2). 
Figura 2 - Publicidades da segunda fase da campanha
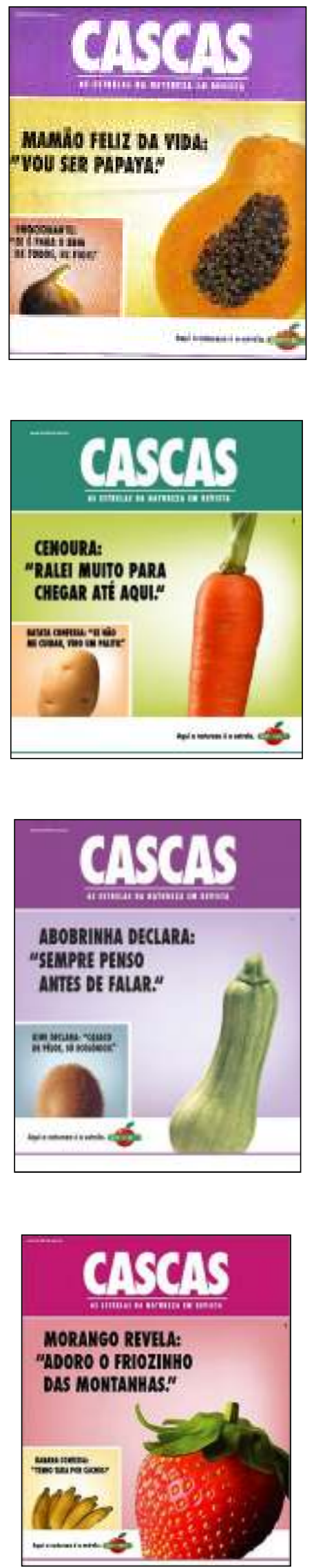
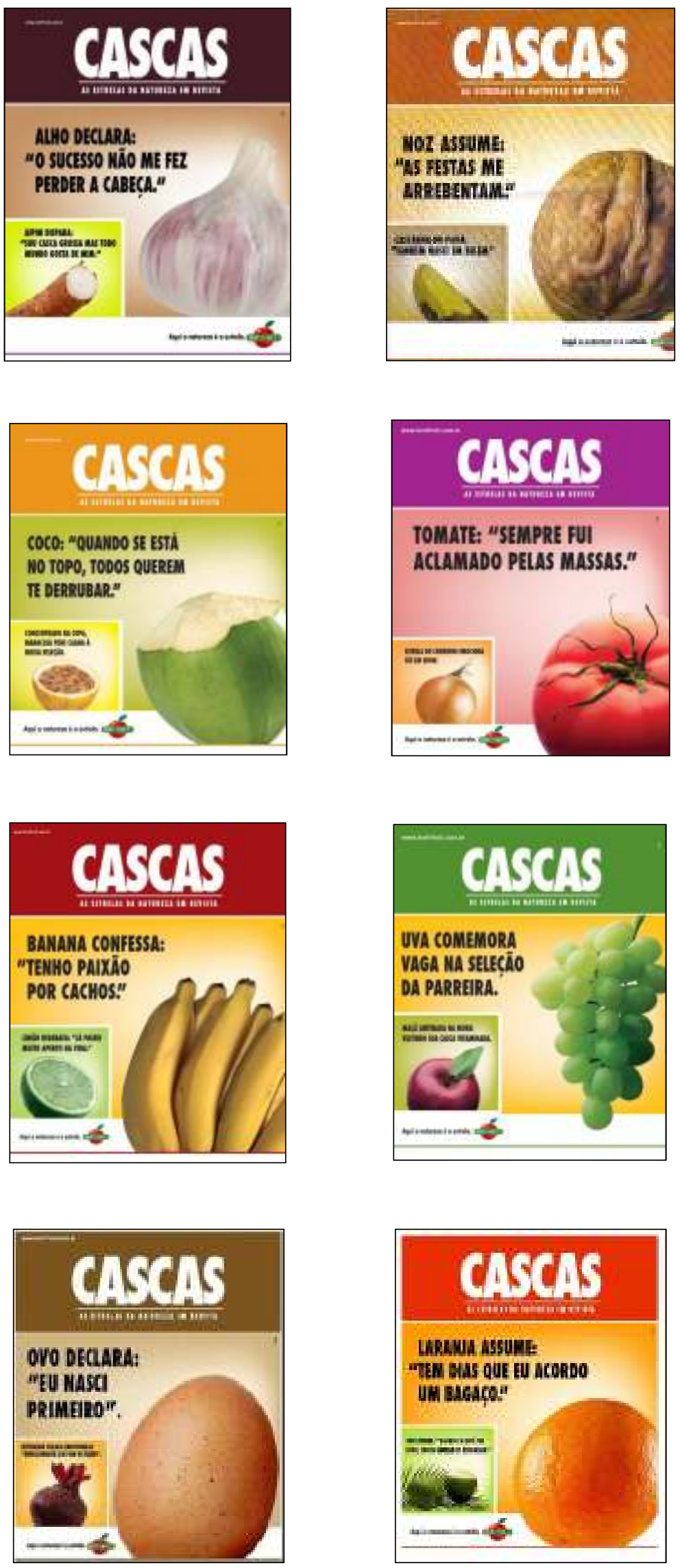

Fonte: www.hortifruti.com.br 
O discurso dessa campanha foi sustentado pela combinação de recursos icônicos e semiolinguísticos, no intuito de convencer o consumidor a adquirir um produto, por meio de frases curtas, linguagem e léxico simples e no apelo ao universo cultural do leitor/cliente. Tudo funciona como uma estratégia discursiva: ao mesmo tempo em que se aproxima do leitor, permitindo-lhe uma leitura fácil, deixa alguns elementos implícitos, que atuam de modo inusitado, provocando associações intertextuais e, por isso, sensações de humor e de bem-estar.

$\mathrm{Na}$ análise das quatro fases da campanha da Hortifruti, uma das características que mais se destacam é a antropomorfização, isto é, a atribuição de qualidades e sentimentos humanos a frutas, verduras e legumes. O uso desse recurso retórico faz parte de uma linguagem criativa, que mistura elementos semânticos das palavras com cores, formas, imagens e elementos gráficos, num processo semiótico. Tudo com o objetivo de fazer a Rede Hortifruti interagir com os consumidores.

Outras estratégias foram os elementos culturais: a intertextualidade, que consiste na citação e na apropriação de aspectos presentes em outros textos, foi estendida a outros tipos de discursos, em sentido amplo: a músicas, filmes e até a uma revista de circulação semanal, destinada a um público específico. Já o humor, obtido a partir de chistes, que apelam para a capacidade de entendimento e de conivência do leitor/cliente, acentua a relação entre os interlocutores (vegetais e clientes). Para compreender o texto humorístico, o leitor precisa dominar uma série de informações, o que lhe permitirá decifrar cada texto. As estratégias mobilizadas consideram que o Sujeito Destinatário as domina.

Os elementos linguísticos, gráficos e visuais foram combinados estrategicamente, de forma a produzir um cenário capaz de interessar o cliente/leitor e de atraí-lo. Tendo sua atenção dirigida para o texto publicitário, por uma primeira vez, e tendo sido conquistado pelo jogo desses elementos, o leitor incorpora esses traços positivos à sua memória e se dispõe à recepção de novos textos. É exatamente a sequência de textos, com a alternância de vozes, mas com a manutenção da carga informativa básica, que faz com que o leitor se deixe seduzir e persuadir. Cria-se um vínculo entre o leitor e a Hortifruti, mediado pelos textos publicitários, fazendo com o leitor se torne um cliente.

Os textos das quatro fases vão ao encontro do postulado da Situação de Comunicação, tal como proposto por Patrick Charaudeau. Representando o sujeito emissor, há um sujeito comunicante (EUc), que são os autores da campanha; os sujeitos enunciadores (SUe) são representados pelos vegetais que dão seus depoimentos na primeira fase da campanha. O receptor ideal da mensagem, para quem são dirigidas as estratégias discursivas, é o sujeito destinatário (TUd), a imagem que se constrói desse cliente, base para a construção dos textos publicitários e suas estratégias narrativas e semióticas; e o sujeito interpretante (SI) é aquele leitor real, concreto, que irá ler os textos e decidir se se torna, ou não, um cliente. Assim, EUc e TUi são pessoas físicas, de carne e osso. Já o EUc e o TUd são estratégias pensadas para conseguir a persuasão do leitor e sua transformação num cliente.

O processo de comunicação descrito é um modo de se fazer gestão do conhecimento: o Euc parte do conhecimento que tem, e que supõe estar também de posse do leitor (SI), utilizando-o para atrair e manter a atenção desse leitor, incutindo-Ihe uma sensação prazerosa de reconhecimento e de cumplicidade. No texto publicitário, um vegetal fala a linguagem do cliente e mobiliza os mesmos conhecimentos. Por isso ser estranho, diferente e engraçado, é capaz de transformar o leitor em consumidor. Esse processo remete 

MUYLDER

também ao conceito de formação discursiva, desenvolvido por Foucault (1986). Nele se pressupõe que emissor e receptor compartilhem um mesmo universo cultural e discursivo.

Na primeira fase da campanha, foram usadas frases comuns, pertencentes ao quotidiano de todos os leitores, com pequenas variações: frases feitas, galanteios, provérbios e menção a situações conhecidas: ascensão social, uso de silicone, amargor da vida, por exemplo.

Os textos publicitários da segunda fase consistem em depoimentos dados pelos vegetais, parodiando situações semelhantes às da revista Caras. Observa-se um processo de citação, em que as falas dos vegetais são colocadas entre aspas. Alguns textos fazem explicitamente referência à marca Hortifruti (batata, milho e abacaxi), enquanto outros mencionam situações sociais: a ascensão social da batata (vim de baixo), a opção sexual da alface (assumo, sou fresca) e a ironia do melão (siliconada, eu?), referindo-se ao uso de silicone nos seios femininos.

Além das estratégias mencionadas, outras também mobilizam o conhecimento prévio do leitor: a cor da goiaba relaciona-se com as cores da Escola de Samba da Mangueira e o jiló é amargo; a dicção especial do milho (milhó) e a associação dos ovos a duplas sertanejas remetem a origens interioranas que muitos leitores têm ou reconhecem. Todas essas estratégias, além do imaginário comum, realizam jogos de palavras, trocadilhos, alusões, quase todos utilizando o humor como estratégia comum. Esse humor, como já se indicou, se origina também do inesperado, do chiste, tal como se vê no texto publicitário em que o figo é relacionado ao "fico", fato histórico brasileiro. 
Figura 3 - Publicidades da terceira fase da campanha
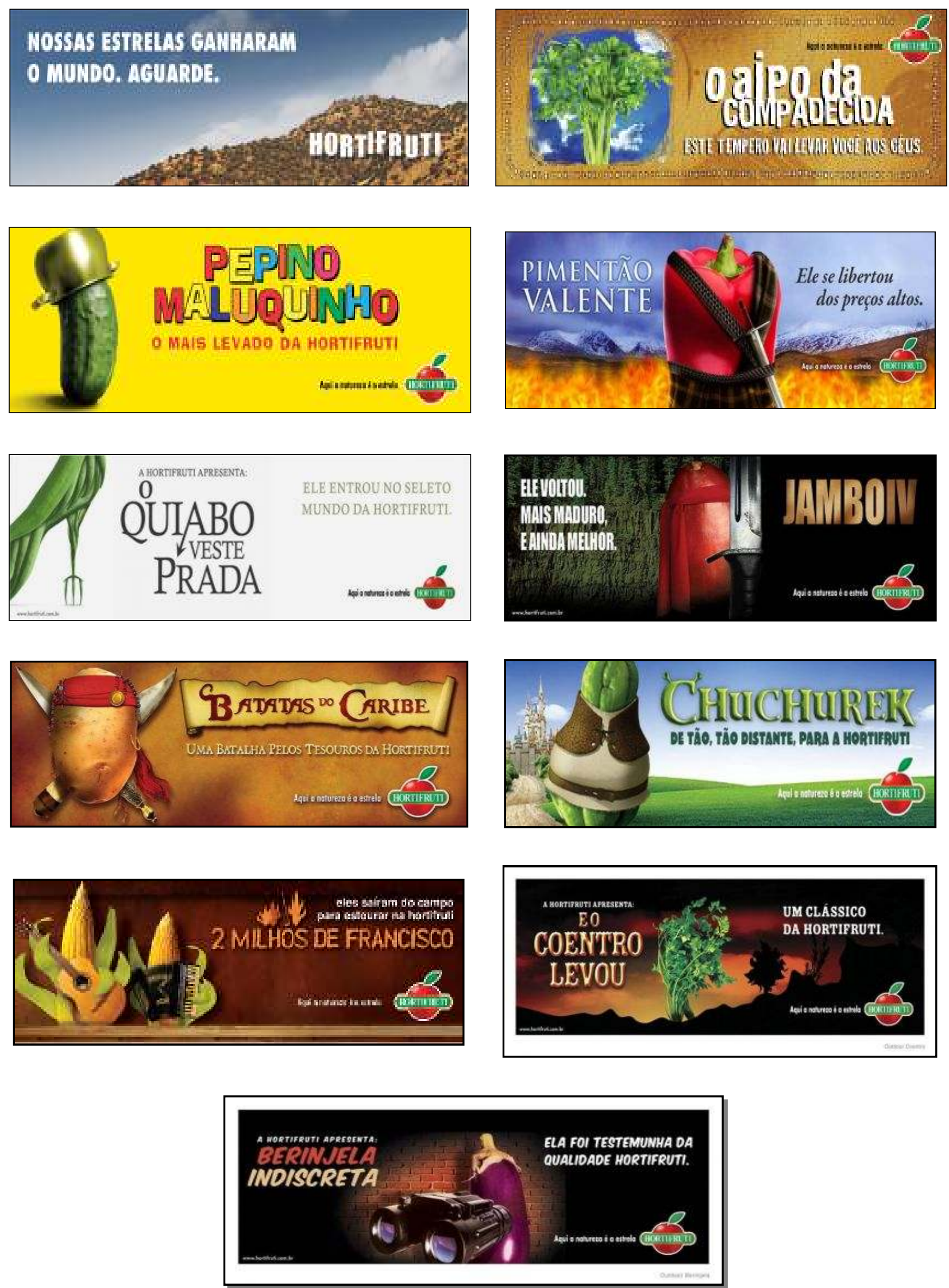

Fonte: www.hortifruti.com.br 
O uso da contextualização, inserindo o tempo dos textos no tempo dos leitores, está presente no momento histórico do dia do fico (figo); nas festas de final de ano, "as festas me arrebentam" e "também nasci em Belém" (noz e castanha); na época da copa, com a palavra "concentração (maracujá); e na alusão ao nome do técnico Parreira (uva). As relações comportamentais podem ser identificadas com "não perder a cabeça" (alho); "todos querem te derrubar" (coco); "vim de baixo" (beterraba), que retoma o depoimento da batata. As expressões a seguir utilizam termos também presentes no cotidiano do leitor: "casca grossa", "ralar", "virar palito", "massas", "falar abobrinha", "antenada" "acordar um bagaço", em que há o jogo entre o aspecto referencial e o metafórico. As referências à vaidade, presente no dia-a-dia do leitor, podem ser observadas em: "se não me cuidar, vou virar palito", "tem dias que acordo um bagaço", "antenada na moda", "sou uma estrela"; o erotismo surge no texto da banana, com sua "paixão por "cachos".

$\mathrm{Na}$ terceira fase, referente a cartazes de filmes, os jogos de palavras embasados pelas rimas e ritmos como menino/pepino, pimentão/coração, diabo/quiabo, limão/missão, rambo/jambo, espião/espigão, filhos/milhos, piratas/batatas, Sherek/chuchurek, tesouro/cenoura, noviças/hortaliças, semanas/cebolas, janela/berinjela, face/alface, benjamim/amendoim, torres/couves. Todos os cartazes remetem aos cartazes originais, com as cores e os índices principais de cada filme, como: o céu do aipo, a panela do Menino Maluquinho, as vestimentas semelhantes às dos personagens originais (pimentão, quiabo, chuchu, jambo, espiga, batata, hortaliças, tomate); os instrumentos usados pelos personagens originais são encontrados nos ficcionais (binóculo-berinjela, instrumentos musicais-milho); a posição dos produtos comparados com os originais como a couve-flor, o melão; ou o sufixo "ão" para realizar a relação com as palavras originais, como espião/espigão e coração/pimentão.

As paródias dos filmes indicam que os produtos são tão famosos quanto os filmes originais e demonstram suas qualidades físicas por meio de uma imagem lúdica. Nos cartazes parodiados dos filmes, os textos verbais fornecem explicações que completam a imagem e relacionam-se ao conteúdo dos filmes originais, orientando a leitura e a interpretação dos anúncios. 
Figura 4 - Publicidades da quarta fase da campanha
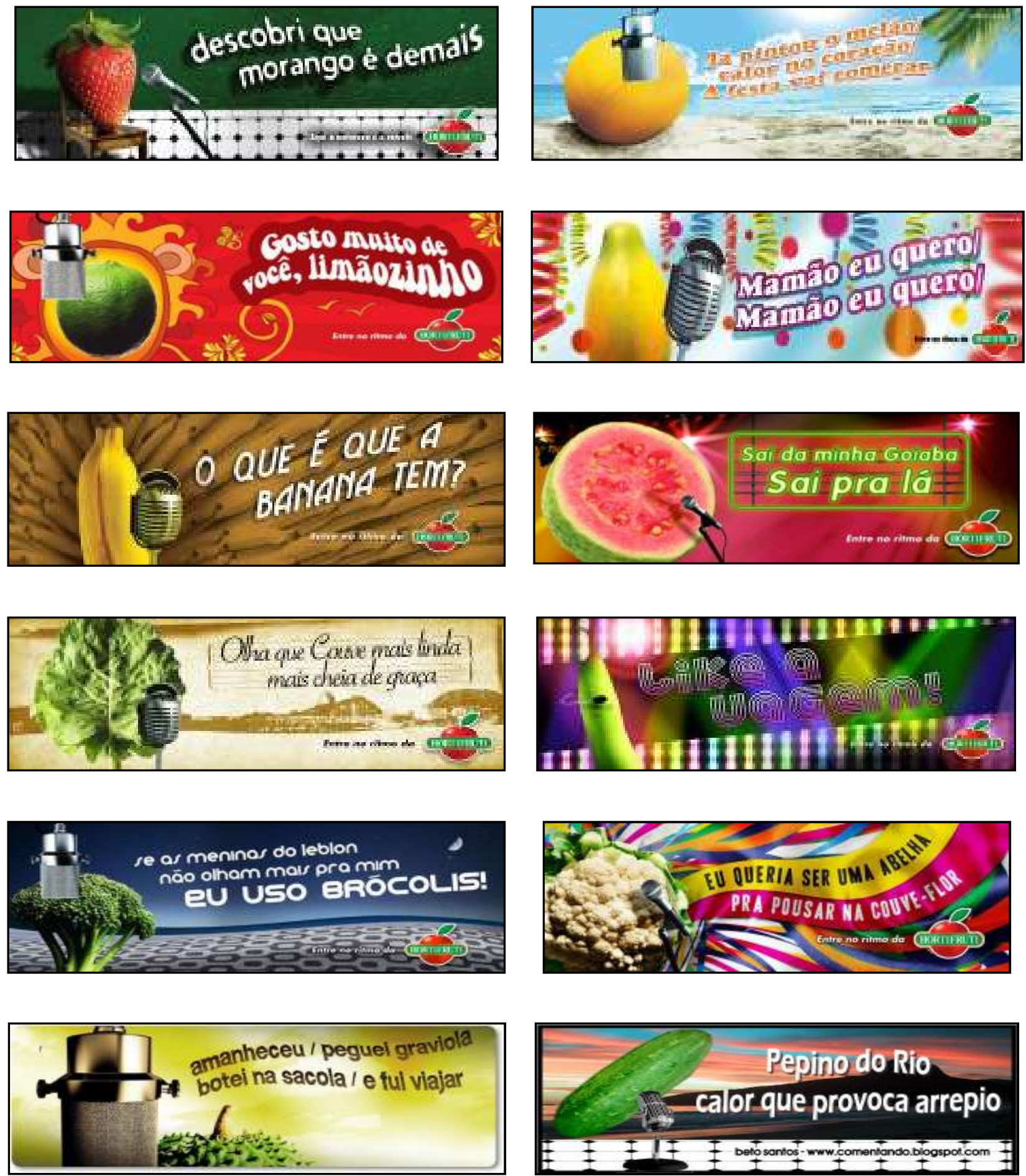

Fonte: www.hortifruti.com.br

Diferentes estilos musicais foram apresentados nos anúncios da quarta fase, relacionandos a uma possível pluralidade de públicos/leitores/consumidores: pagode (morango, goiaba), a marchinha de carnaval (banana), a MPB (Leãozinho-limão), Garota de Ipanema (couve), Menino do Rio (pepino), Aja amor (couveflor), o axé (repolho) o rock (brócolis), o sertanejo (graviola), Like a Virgin (vagem). Várias rimas e semelhanças fonéticas foram usadas: melão/verão, leãozinho/limãozinho, mamão/mamãe, baiana/banana, goiaba/aba, "repolhation"/rebolation, menino/pepino, graviola/viola. Recria-se o ambiente original: a couve e 
o calçadão, o pepino e o Rio, o melão e a praia, o mamão e o carnaval. Dois bairros cariocas estão presentes: o Leblon e Ipanema. Alguns produtos fazem menção aos intérpretes das músicas como a couve-flor com as fitinhas de Salvador (Luiz Caldas) ou o morango e o cenário de um bar (Zeca Pagodinho).

As 75 entrevistas realizadas com clientes foram utilizadas para se verificar a eficácia da campanha. Vários entrevistados (20) tiveram uma postura positiva em relação aos anúncios e os consideram criativos; outros (12) os julgaram divertidos e engraçados. 19 consideraram excelentes, espetaculares, sensacionais, bonitas e até marcantes, enquanto nove disseram serem bons os anúncios, sete os classificaram como interessantes, cinco como funcionais e objetivos. Apenas um disse ser enganoso o anúncio.

\section{CONCLUSÃO}

A questão de pesquisa pretendia verificar de que maneira o uso de recursos semiodiscursivos configuraria uma estratégia de atratividade de clientes. A partir dela, estabeleceu-se um percurso de análise em que se consideraram, de um lado, as estratégias semiodiscursivas presentes nos textos publicitários das quatro campanhas da Hortifruti e, de outro, os efeitos que essas estratégias provocaram nos clientes da rede varejista.

Considerando-se o processo de comunicação proposto por Charaudeau (2010), que relaciona dois pares de sujeitos: de um lado, o sujeito comunicante (EUc) e o sujeito enunciador (EUe); de outro, o sujeito destinatário (TUd) e o sujeito interpretante (TUi), procurou-se identificar e analisar as estratégias discursivas, estabelecidas entre TUi e TUd, sujeitos do discurso, a partir do processo de gestão da informação mobilizado entre EUc e TUi, sujeitos sociais.

Para isso, considerou-se que ambos os sujeitos sociais (EUc e TUi) pertencem a uma mesma formação discursiva e, portanto, têm acesso a universos lexicais, sintáticos e semânticos comuns a uma mesma cultura (MORGAN, 2007). Isso possibilita que eles se comuniquem e restringe as possibilidades mútuas de incompreensão. Pode-se dizer que a recepção das mensagens fica condicionada à forma como elas se estruturam e às informações que mobilizam. Sem que haja essa sintonia, ou essa comunidade entre emissor (EUc) e receptor (TUi), a comunicação não se fará ou não será otimizada.

$O$ receptor de uma mensagem (TUi) deve possuir habilidades que the permitam reconhecer os sinais linguísticos usados, os signos formados por esses sinais, as frases, que são conjuntos de signos, e, por fim, o texto como suporte e como unidade de comunicação. Além disso, precisa incluir esse texto num contexto mediato e imediato, que inclui e ultrapassa o processo de comunicação em curso. $O$ emissor da mensagem (EUc), ao compô-la, a direciona para um receptor específico, ainda que faça apenas uma imagem (baseada em dados e informações) desse receptor, que é o sujeito destinatário (TUd). Assim, supõe que o TUd tenha determinados conhecimentos, possua certas habilidades, sendo capaz de ir além da decodificação do texto escrito e de entendê-lo nos seus implícitos. Portanto, a significação de um texto dependerá do que contém e, além disso, da capacidade do leitor em reconhecer o que está contido ali. O par formado pelo sujeito destinatário (TUd) e pelo sujeito interpretante (TUi), que se confundem, pode não apenas ler o que foi escrito pelo par formado pelo sujeito comunicante (EUc) e pelo sujeito enunciador (EUe), mas pode ir além e ler outras coisas, que estavam subentendidas ou ocultas no texto original. 
A análise da estrutura semiodiscursiva dos textos publicitários da campanha atingiu o primeiro objetivo proposto, ao indicar os elementos semióticos e discursivos utilizados em cada fase. Essa análise mostrou que esses elementos mobilizaram palavras, jogos de palavras, alusões, duplos sentidos, metáforas, e exigiram do leitor uma informação mais depurada acerca de filmes, livros, músicas e situações culturais, além da capacidade de leitura das relações intertextuais, paródicas e humorísticas provocadas pelas peças publicitárias. Criou-se uma relação empática, e bem-humorada, com o leitor - cliente. Esse leitor/cliente se caracteriza como pertencente a uma determinada classe social (média alta), com um poder aquisitivo elevado, e a análise, ao mesmo tempo em que atinge o segundo objetivo, caracteriza a estratégia semiodiscursiva como uma estratégia de marketing que seduziu, persuadiu, atraiu e fidelizou seus destinatários, leitores e clientes. Responde-se, pois, à questão de pesquisa, tendo ficado demonstrado que as estratégias semiodiscursivas se configuraram como uma estratégia de marketing, para atratividade e retenção de clientes.

Notas:

http://www.mppublicidade.com.br/

\section{REFERÊNCIAS}

BAKHTIN, M. (Volochínov). Marxismo e filosofia da linguagem. Tradução de Michel Lahud, Yara F. Vieira. 2. ed. São Paulo: Hucitec, 1981

BARBOSA, I. S.; TRINDADE, E. Por uma enunciação publicitária. In: CONGRESSO LATINO-AMERICANO DE ESTUDOS DO DISCURSO, 2., 2003, Puebla. Anais... Puebla, Universidad Autónoma Benemérita de Puebla/ALED, 2003.

BARTHES, R. Mitologias. Tradução de Rita Buongermino, Pedro de Souza. São Paulo: Difusão Européia do Livro, 1972. BARTHES, R. Novos ensaios críticos seguidos de O grau zero da escritura. Tradução de Heloysa de Lima Dantas et al. São Paulo: Cultrix, 1974.

BAUMAN, Z. Modernidade líquida. Tradução de Plínio Dentzien. Rio de Janeiro: Jorge Zahar Editor, 2001.

BERGSON, H. O riso: ensaio sobre a significação do cômico. 2. ed. Rio de Janeiro: Zahar Editores, 1983.

BERRY, L. Relationship marketing of services perspectives from 1983 and 2000. Journal of Relationship Marketing, [S. I.], v. 1, n. 1, p. 59-77, 2002.

BOURDIEU, P. A economia das trocas simbólicas. Tradução de Sérgio Miceli et al. 2. ed. São Paulo: Perspectiva, 1982.

CAFFERKY, M. E. Venda boca-a-boca: deixe seus clientes fazerem a propaganda. São Paulo: Nobel, 1999.

CAMPOMAR, M. C.; IKEDA, A. A. Falácias em marketing no Brasil. In: EMA, 2006, Curitiba. Anais... Curitiba: EMA, 2006.

CARVALHO, N. M. de. O discurso publicitário. Comunicação: Veredas - Revista do Programa de Pós-Graduação em Comunicação, Marília, Ano 3, n. 3, p. 207-222, 2004.

CASTRO JÚNIOR, D. F. L. de, et al. Marketing! Onde está o paradigma? REMark - Revista Brasileira de Marketing ReMark, [S. I.], v. 14, n 3, p. 350-361, jul./set. 2015.

CHARAUDEAU, P. Discurso das mídias. Tradução de Ângela M. S. Corrêa. São Paulo: Contexto, 2009.

CHARAUDEAU, P. Linguagem e discurso: modos de organização. Tradução de Ângela M. S. Corrêa e Ida Lúcia Machado (Coord.). 2. ed. São Paulo: Contexto, 2010.

CHARAUDEAU, P. Uma análise semiolinguística do texto e do discurso. In: PAULIUKONIS, M. A. L.; GAVAZZI, S. (Org.). Da língua ao discurso; reflexões para o ensino. Rio de Janeiro: Lucerna, 2005. p. 11-27, 2005. Disponível em: <http://www.patrick-charaudeau.com/Uma-analise-semiolinguistica-do.html>. Acesso em: 15 dez. 2012.

CHARAUDEAU, P.; MAINGUENAU, D. Dicionário de Análise do Discurso. Tradução de Fabiana Comesu. 2. ed. São Paulo: Contexto, 2006.

CHURCHILL JR., G.; PETER, J. Marketing: criando valor para os clientes. São Paulo: Saraiva, 2000. 


\section{FLÁVIO EVERTON DE CASTRO, LUIZ CLAUDIO VIEIRA DE OLIVEIRA, CRISTIANA FERNANDES DE MUYLDER}

COBRA, M. H. N. Administração de marketing. São Paulo: Atlas, 1992.

CROCOO, L.; GIOIA, R. (Coord.). Fundamentos de marketing: conceitos básicos. São Paulo: Saraiva, 2006. (Coleção de Marketing, v. 1).

DURAND, J. Rhétorique et image publicitaire. Paris : Seuil, 1970.

FELDMANN, A.; SANT'ANNA, M. Semiótica e percepção na campanha publicitária "O câncer de mama no alvo da moda". In: CONGRESSO BRASILEIRO DE CIÊNCIAS DA COMUNICAÇÃO, 30., 2007, Santos. Anais... Santos: Intercom, 2007.

FARIA, L. H. L., et al. 20 anos de publicações sobre marketing de relacionamento no Brasil: uma análise da produção acadêmica de 1992 a 2012. Revista Brasileira de Marketing - ReMark, [S. I.], v. 13, n. 1, jan./mar. 2014.

FIRAT, A. F. Marketing: Culture Institutionalized. Journal of Macromarketing, [S. I.], v. 33, n. 1, p. 78-82, 2012.

FOUCAULT, M., et al. Estruturalismo e teoria da linguagem. Tradução de Luiz Felipe B. Neves. Petrópolis: Vozes, 1971.

FOUCAULT, M. A arqueologia do saber. Tradução de Luiz Felipe Baeta Neves. Petrópolis: Vozes, 1972.

FREDERICO, E., et al. Valor, satisfação e recomendação espontânea para uma marca varejista. Revista Brasileira de Marketing - ReMark, [S. I.], v. 13, n. 6, p. 107-123, out./dez. 2014.

GONÇALVES, E. P.; MACHADO, M. B. E.; MARQUES, R. Marketing de relacionamento para fidelizar clientes. Gestão Contemporânea, [S. I.], v. 2, n. 1, 2012.

HORTIFRUTI comemora 20 anos com exposição de anúncios premiados na estação do Metrô da Carioca. 14 out. 2009. Disponível em: <http://www.portaldapropaganda.com.br/portal/propaganda/14021-hortifruti-comemora-20-anos-comexposicao-de-anuncios-premiados-na-estacao-do-metro-da-carioca>. Acesso em: 9 set. 2015.

HORTIFRUTI. Disponível em: <www.hortifruti.com.br>. Acesso em: 15 abr. 2012.

HOLANDA, S. M. M. Os antecedentes da lealdade no contexto bancário: um estudo com clientes do segmento empresa. 2008. 347 f. Tese (Doutorado em Organização e Gestão de Empresas na Especialidade de Estratégia e Comportamento Organizacional) - Universidade de Coimbra, Coimbra, 2008.

ISABELLA, G.; BARROS, L. S. G.; MAZZON, J. A. A influência do constrangimento do consumidor no processo de compra. Revista de Administração Contemporânea, Curitiba, v.19, n. 5, p. 626-648, set./out. 2015.

JAPPE, R. Quando design e publicidade andam juntos. Design culture, 01 ago. 2014. Disponível em: <http://www.designculture.com.br/quando-design-e-publicidade-andam-juntos/>. Acesso em: 09 set. 2015.

KOCH, I. G. V. O texto e a construção dos sentidos. 10. ed. São Paulo: Contexto, 2011.

KOTLER, P. Administração de marketing: a edição do novo milênio. São Paulo: Prentice Hall, 2000.

KOTLER, P. Administração de marketing: análise, planejamento, implementação e controle. São Paulo: Atlas, 2005.

KOTLER, P.; KELLER, K. L. Administração de marketing. 12. ed. São Paulo: Pearson Prentice Hall, 2006.

LAS CASAS, A. L. Marketing: conceitos, exercícios, casos. São Paulo: Atlas, 1997.

LÉVI-STRAUSS, C. Antropologia Estrutural. Tradução de Chaim Samuel Kats, Edinardo Pires. Rio de Janeiro: Tempo Brasileiro, 1975.

LOYOLA, L. C. O planejamento de campanha. Destarte - Revista Científica dos Cursos de Administração, Jornalismo, Publicidade e Propaganda e Turismo da Faculdade Estácio de Sá de Vitória, Vitória, v. 1, n. 1, 2011.

MACHADO, I. L. A paródia vista sob a luz da análise do discurso. In: MARI, H. et al. (Org.). Fundamentos e dimensões da análise do discurso. Belo horizonte: Carol Borges, Núcleo da Análise do Discurso FALE-UFMG, 1999.

MACHIN, D.; VAN LEEUWEN, T. Global Media Discourse: A critical introduction. New York: Routledge, 2007.

MELLO, S. C. B. O que é conhecimento de marketing no Brasil. RAC - Revista de Adminis ᄀtração Contemporânea, [S. I.], v. 10, n. 2, p. 203-212, abr./jun. 2006.

MORGAN, G. Imagens da organização. São Paulo: Atlas, 2007.

NÓBREGA, P. C. As novas mídias: o mobiliário urbano como ferramenta de comunicação diferenciada e eficaz na publicidade dos dias de hoje. 2011. Monografia (Pós-graduação Lato Sensu em Comunicação Empresarial) Universidade Cândido Mendes, Rio de Janeiro, 2011.

NUNES, M. F. H.; FERREIRA, S. M.; MOURA, S. A. A linguagem enquanto ação e o processo de referenciação em peças publicitárias da Hortifruti. In: CONGRESSO BRASILEIRO DE CIÊNCIAS DA COMUNICAÇÃO, 35., 2012, Fortaleza. Anais... Fortaleza: Intercom, 2012.

OLIVER, R. Whence consumer loyalty? Journal of Marketing, [S. I.], v. 63, p. 33-44, 1999. Special Issue.

ORLANDI, E. P. Análise do discurso: princípios e procedimentos. 7. ed. Campinas: Pontes, 2007. 
ORLANDI, E. P. Discurso e texto, formação e circulação dos sentidos. Campinas: Pontes Editora, 2001.

PALMER, A. The evolution of an idea: an environmental explanation of relationship marketing. Journal of Relationship Marketing, [S. I.], v. 1, n. 1, p. 79-94, 2002.

PARVATIYAR, A.; SHETH, J. The domain and conceptual foundations of relationship marketing. In: SHETH, J.; PARVATIYAR, A. Handbook of relationship marketing. Thousand Oaks: Sage, 2000.

PEREZ, C. Gestão e Semiótica da marca: a publicidade como construção e sustentação sígnica. In: CONGRESSO BRASILEIRO DE CIÊNCIAS DA COMUNICAÇÃO, 30., 2007, Santos. Anais... Santos: Intercom, 2007.

PIETROFORTE, A. V. Análise do texto visual: a construção da imagem. 2. ed. São Paulo: Contexto, 2011.

SANDMANN, A. A linguagem da propaganda. São Paulo: Contexto, 2003.

SANT'ANNA, A. Propaganda: teoria, técnica e prática. São Paulo: Pioneira Thomson Learning, 2002.

SANTAELLA, L. O que é semiótica. São Paulo: Brasiliense, 1999.

SANTAELLA, L. Semiótica aplicada. São Paulo: Thomson Learning, 2007.

SAUSSURE, F. de. Curso de linguística geral. Tradução de Antônio Chelini, Izidoro Blikstein, José Paulo Paes. 27. ed. São Paulo: Cultrix, 2006.

SEQUINI, L. A importância do marketing para conquistar e fidelizar clientes. Revista Teste, Andradina, v. 2, n. 2, p. 1120, 2013.

TODOROV, T. Teorias do símbolo. Tradução de Maria de Santa Cruz. Lisboa: Edições 70, 1979.

TORRES, C. V.; ALLEN, M. W. Influência da cultura, dos valores humanos e do significado do produto na predição de consumo: síntese de dois estudos multiculturais na Austrália e no Brasil. RAM - Revista de Administração Mackenzie, São Paulo, v. 10, n. 3, p. 127-152, 2009.

VERGARA, S. M. C. Métodos de pesquisa em administração. São Paulo: Atlas, 2008.

YIN, R. K. Estudo de caso: planejamento e métodos. 3. ed. Porto Alegre: Bookman, 2005.

ZENONE, L. C. (Org.). Gestão estratégica de marketing. São Paulo: Atlas, 2011. 